\title{
LA CAMARA SANGRIENTA: TRANSTEXTUALIDAD Y TRANSMEDIALIDAD EN EL LIBRO ILUSTRADO
}

\author{
TRANSTEXTUAL AND TRANSMEDIAL RELATIONS \\ IN THE ILLUSTRATED BOOK: THE BLOODY CHAMBER
}

\author{
Carmen V. VIDAURE ARENAS \\ Universidad de Guadalajara (México) \\ carmen.vidaurre@academicos.udg.mx
}

\begin{abstract}
Resumen: Analizamos La cámara sangrienta (2017) de Angela Carter, ilustrada por Alejandra Acosta, a partir de aportaciones sobre la transtextualidad (Genette, 1989), las narrativas transmedia (Jenkins, 2003; Long, 2007; Scolari, 2013) y los volúmenes integrados (Brecia y Romano, 2006). Buscamos dar prioridad al estudio de las variadas dinámicas intersemióticas, destacar la importancia de la contextualización y las competencias culturales de los receptores en los procesos de interpretación. El análisis de las ilustraciones permite observar la forma en que ponen en crisis su caracterización como elementos accesorios y destacar que el concepto de traducción intersemiótica resulta inexacto para describir los fenómenos que se verifican en las obras ilustrada analizada.
\end{abstract}

Palabras clave: Angela Carter. La cámara sangrienta. Transtextualidad. Transmedia. Libro ilustrado. Análisis de la imagen.

Abstract: We analyze The Bloody Chamber by Angela Carter, illustrated by Alejandra Acosta, from some contributions on transtextuality (Genette, 1989), transmedia narratives (Jenkins, 2003; Long, 2007; Scolari, 2013) and integrated volumes (Brecia y Romano, 2006). We seek to give priority to the study of the various intersemiotic dynamics, highlighting the importance of contextualization and the cultural competencies of the receivers. The analysis of the illustrations allows us to observe the way in which they come to put in crisis their characterization as accessory 
elements or disconnected from the semiotic processes and to emphasize that the translation concept intersemiotic is inaccurate to describe some of the phenomena in the illustrated work.

Key Words: Angela Carter. The Bloody Chamber. Transtextuality. Transmedia. Illustrated book. Analysis of the image.

\section{INTRODUCCIÓN}

Las obras que participan de diferentes sistemas sígnicos, como los libros ilustrados, han sido denominadas multimodales (Kress y Van Leeuwen, 2001; Kress, 2003), plurimediales (Wolf, 2009: 14) y multimediales (Torop, 2002: 9). Sus imágenes han sido estudiadas a la luz del concepto de traducción intersemiótica de Jakobson (1987: 428-435), y de traducción entre textos de Torop, entendida como proceso mediante el cual un texto se transforma en otro, incluso de un sistema semiótico diferente (Torop, 2000, 2002).

Aquí analizamos La cámara sangrienta (2017) de la escritora británica Angela Carter, ilustrada por Alejandra Acosta ${ }^{1}$ a partir de algunas aportaciones sobre la transtextualidad (Genette, 1989: 9-17), la intertextualidad (Dällembach, 1976; Eco, 2003), los volúmenes integrados (Brecia y Romano, 2006) y la retórica de la imagen (Barthes, 1992; Grupo $\mu, 1993)$. Porque buscamos ejemplificar la forma en que el concepto de traducción en su sentido más amplio (traducción cultural), y en que lo entienden Jakobson y Torop, resulta inexacto para describir los fenómenos que se verifican en la obra ilustrada, al mismo tiempo que damos prioridad al estudio de las dinámicas intersemióticas, la contextualización y competencias culturales del receptor, en los procesos de significación e interpretación de los signos visuales. Consideramos también relaciones entre la transtextualidad y transmedialidad (Jenkins, 2003; Long, 2007;

\footnotetext{
${ }^{1}$ Diseñadora gráfica chilena. Ha ilustrado: El niño con bigote (2010), Oruam, el pequeño mago (2010), Ecos verdes (2011), Aventuras y orígenes de los pájaros (2011), Del enebro (2012), Bonsai (2012), El árbol (2012), ¿Dónde están mis patatillas? (2014), Cosmotheoros (2015), Malulito maldadoso (2015), Amor (2015), 100 Writing Days (2016), Las relaciones peligrosas (2016), La mujer de la guarda (2016), Empatía (2017), Aura (2017), Atlas del bien y del mal (2017), Axolotl (2018).
} 
Scolari, 2013) en el libro analizado.

El libro ilustrado para adultos antecedió al libro para niños (Erro, 2000: 501). Diversos trabajos han señalado el papel de las ilustraciones como elementos que no siempre dependían del escrito (Henry, 1951: 79), ni eran meramente ornamentales, pues se podía tratar de componentes atrevidamente transgresores, que adquirían marcado protagonismo, y que lo mismo podían guardar relación estrecha con el escrito, siendo análogos a una glosa visual del texto (Camille, 1992), pero también podían involucrar otros contenidos, generando dinámicas complejas e incluso contradictorias (Planas, 2009). La iluminación "formaba parte de la producción integral del manuscrito" (Gutiérrez, 1999: 54), podía realizarse previamente o $a$ posteriori (Gutiérrez, 1999: 54, Falcón, 1999:81), incluso cumplía con características que hoy sirven para definir el álbum ilustrado, como obras que introducen con sus imágenes la ruptura de la linealidad discursiva, en las que "la interacción palabras/imágenes se cuestiona, reformula y enriquece" (Di Marco, 2017: 355), permitiendo "mayores complicaciones estructurales" (Turrión, 2012: 60), demandando un mayor esfuerzo interpretativo. Se trataba de obras caracterizadas por una compleja imbricación de lenguajes, en las que las grafías se usaban como imágenes, y el color, las formas, los elementos espaciales, desempeñaban un papel primordial, que hacían evidentes microestructuras narrativas, imaginarios culturales y contenidos simbólicos (Di Marco, 2017: 357). Muchos de los ilustradores de esas obras fueron anónimos.

Al considerar obras literarias ilustradas más contemporáneas, el análisis de las imágenes que las acompañan se ha realizado, dominantemente, cuando el ilustrador es el escritor o un artista consagrado, pese a que destacados autores han producido obras que integraron imágenes, desde la instancia autoral y no sólo editorial, no producidas por ellos o consagrados $\operatorname{artistas}^{2}$. Lo señalado cambia cuando consideramos estudios aplicados al álbum y libro ilustrado para niños, pues encontramos numerosos trabajos dedicados al tema (Colomer, 2010; Durán, 2009; Sipe, 2008; Hanán, 2007; Viana, 2003, etc.).

El incremento de libros ilustrados, interactivos, motion comics, que se suman a otras modalidades precedentes ${ }^{3}$, crea un nuevo interés

${ }^{2}$ Julio Cortázar, Julián Ríos, etc.

${ }^{3}$ Animación, narrativa gráfica, cine, videojuegos, etc. 
por el estudio de las relaciones entre imágenes y palabras, que ha puesto en evidencia la necesidad de replanteamientos teóricos y la recuperación de aportaciones previas. A esto se añade la necesidad de considerar conceptos, como el de transmedia (Jenkins, 2003; Scolari, 2013), que se ha ampliado: "Al ámbito del entretenimiento y la ficción audiovisual, en que se suele focalizar hoy el estudio de las narraciones transmedia, hemos sumado los de la información periodística, el activismo, la literatura y el arte" (Rodríguez y Peñamarín, 2014: 9). Concepto que, como otros, convendría evaluar desde la perspectiva de las aportaciones semióticas y el análisis textual. Esto no significa que no se hayan producido esfuerzos por integrar aportaciones formuladas en el ámbito del análisis textual y los transmedia. Sin embargo, en ocasiones se trata de propuestas que deben someterse a "una síntesis unitaria" (Gil y Pardo, 2018: 13), pues la terminología resulta solamente "congruente dentro del modelo específico propuesto por cada uno de los autores y ensayos concretos" (Gil y Pardo, 2018: 14). Fenómeno que se agrava cuando se emplean en los trabajos términos especializados sin indicar la obra de la que se toman, o con una semántica distinta a la desarrollada en los estudios semióticos y del análisis textual de donde provienen. Pese a esto, hay autores que logran integrar propuestas trandisciplinarias con rigor científico: desde el análisis textual (Crespo, 2017), la semiótica (Berlanga, Arjona y Merino, 2018), o la transmedialidad (Guerrero-Pico y Scolari, 2016), entre otros trabajos más difundidos.

\section{LA OBRA LITERARIA: TRANSTEXTUALIDAD Y TRANSMEDIALIDAD}

La cámara sangrienta (2014) reúne diez relatos ${ }^{4}$, se trata de una obra hipertextual (Genette, 1989: 14-17), por ser una traducción interlingüística (Jakobson, 1971), y porque sus narraciones están basadas en cuentos de tradición oral. Los textos de Carter fueron escritos entre 1975-79, y en las primeras ediciones se presentaban como relatos para adultos, proponiendo una adscripción tipológica desde su título, The Bloody Chamber and Other Adult Tales (1979), architexto (Genette, 1989: 13) que no se conserva en

\footnotetext{
${ }^{4}$ Aunque se ha indicado que es la primera traducción al castellano, la obra ya había sido traducida por Matilde Horne (1991).
} 
la traducción.

Aunque los fenómenos de intertextualidad (Genette, 1989: 10-11) son visibles en los diez escritos, no todos la hacen explícita en su título. "La cámara sangrienta" es una reelaboración del cuento "Barba Azul"; "El cortejo del señor León" y "La novia del tigre", lo son de "La Bella y la Bestia"; "El gato con botas" reinterpreta el relato homónimo; "El rey de los trasgos" es variante de "La hija del rey de los elfos"; "La niña de la nieve" recrea el cuento "La niña, el cuervo y la nieve", variante de "Blancanieves"; "La dama de la casa del amor" relabora "La bella durmiente", que se fusiona con narraciones sobre vampiros. Los relatos: "El hombre lobo", "La compañía de los lobos" y "Lobalicia", derivan de "Caperucita Roja" y de mitos sobre licántropos. Sin embargo, la intertextualidad del libro no se limita a lo señalado, pues se observa la presencia de elementos provenientes de obras de Lewis Carroll, referencias a Là-bas (1891) de Joris-Karl Huysmans, a Carmila (1872) de Sheridan Le Fanu, a Travels into Several Remote Nations of the World, in Four Parts. By Lemuel Gulliver (1726) de Jonathan Swift, la recuperación de tópicos de la narrativa neogótica del siglo XIX y de relatos románticos, referencias a la Comedia del Arte, alusiones musicales, teatrales, arquitectónicas, plásticas y a figuras artísticas ${ }^{5}$, elementos de mitos greco-latinos, así como otros textos señalados por estudiosos de la narrativa de Carter (Piña, 2012: 17).

Los antecedentes del libro son un conjunto de relatos que contaron con numerosas versiones, estableciendo una compleja red transtextual (Genette, 1984), que dificulta identificar la versión específica tomada como hipotexto (Genette, 1989: 14-17). Aunque debemos destacar que las relaciones con cuentos previos no se limitan a la recuperación de la cadena de acciones y funciones (Propp, 1974) — ofreciendo algunas variantes-, atañe también a elementos discursivos, protagonistas y detalles, por lo que, la "nueva producción hace que releamos en ella a sus antecesoras, como en un palimpsesto. Detrás de escenas, elementos, símbolos, podemos percibir los relatos que ya conocemos, y más" (Pérez, 2011: 431). Fenómeno también visible en algunos cuentos de García Márquez ${ }^{6}$, que preceden o son contemporáneos a los de Carter, y en los que se ofrecen nuevas

${ }^{5}$ Los artistas mencionados son personajes históricos, pero algunas de las obras que se señalan no existen.

${ }^{6}$ Como "La triste historia de la Cándida Eréndira y su abuela desalmada" (1974) o "El rastro de tu sangre en la nieve" (1976). 
versiones de cuentos de tradición oral.

Los cuentos que tomó Carter habían involucrado el paso de narraciones verbales a sistemas de signos no verbales, obras multimodales, y abundantes recreaciones literarias: "Barba Azul", por ejemplo, es una tradición oral recopilada por Perrault en Les Contes de ma mère l'Oye (1697), tiene variantes en distintas lenguas, como el cuento italiano "Silvernose" (compilado por Italo Calvino, 2014). Su anécdota inspiró Captain Murderer (1860) de Dickens y Les Sept femmes de la BarbeBleue et autres contes merveilleux (1909) de Anatole France, pero también obras plásticas de Charles Hunt. Fue ilustrado por artistas como Doré, Walter Crane, Arthur Rackham, Harry Clark, entre otros. Dio lugar a composiciones musicales, como la ópera de André Grétry (1789) y la de Béla Bartók (1911), la ópera bufa de Jacques Offenbach (1866), el ballet de Marius Petipa (1896), varios filmes, entre ellos un cortometraje de Méliès (1901), y las películas de Edgar G. Ulmer (1944), Christian-Jaque (1951) y Edward Kmytryk (1972), sólo para referir a algunas obras previas a la versión de Carter.

Lo mismo se aplica a "La Bella y la Bestia", cuyo origen remite al Asno de oro de Apuleyo, tradición narrativa recuperada del folclore italiano por Francesco Straparola en el siglo XVI, y del francés por Suzanne de Villeneuve en siglo XVIII. Ha dado lugar a abundantes obras musicales, teatrales y cinematográficas, de las que sólo destacaremos La Belle et la Bête (1946) de Jean Cocteau y La flor escarlata (1952) de Lev Atamanov. Sus personajes figuran en videojuegos ${ }^{7} \mathrm{y}$ ha gozado de recreaciones musicales $^{8}$.

"El gato con botas" había sido recogido por Straparola y por Basile, en el siglo XVI, luego por Perrault, en el siglo siguiente. Fue ilustrado por célebres artistas y algunas de las páginas de Walter Crane (1914) guardan relación con las planchas de una novela gráfica. Además de figurar en diversos filmes de animación, se pueden encontrar alusiones en series de anime $^{9}$. La versión de Carter fusiona, además, elementos de $\mathrm{Il}$ barbiere di

\footnotetext{
${ }^{7}$ Kingdom Hearts. Se afirma que Shigeru Miyamoto se inspiró en este cuento para el juego de Nintendo Donkey Kong, aunque en él se identificar el argumento de King Kong (considerada variante del cuento).

${ }^{8}$ Fue la base de la canción "I will do anything for love (but I won't do that)". "Beauty and the Beast" es el nombre de la canción del grupo sueco The Ark, y de otra del grupo finlandés Nightwish.

${ }^{9}$ En el anime Pokémon, aparece un Meowth con botas.
} 
Siviglia (de Rossini) y Le nozze di Figaro (ópera bufa de Mozart), obras multimodales derivadas de comedias de Beaumarchais.

"El rey de los trasgos", relato menos difundido y cuyo origen se ha ubicado en Dinamarca, fue recuperado en la balada de Johann G. Herder "Erlkönigs Tochter" ("La hija del rey de los elfos", 1778) y en el poema de Goethe "Erlkönig" ("El rey de los elfos", 1782), al que pondría música Franz Schubert, luego vería otras versiones musicales.

"Blancanieves" fue recopilado por Jacob y Wilhelm Grimm (Cuentos para los niños y el hogar, 1812), una de las versiones más difundidas, junto al largometraje de dibujos animados de Disney. Numerosos artistas lo ilustraron, tiene versiones en cortos animados ${ }^{10}$, cine, novelas gráficas ${ }^{11}$, libros interactivos. Ha pasado de la tradición popular a la culta, y la escritora Elfriede Jelinek, ofrece una versión teatral en Dramas de princesas. La muerte y la doncella I-V (2003-2008). Ha sido utilizado en publicidad, juguetes, disfraces infantiles, dando origen a una multiplicidad de materiales hipertextuales (Genette, 1989: 14-17) y metatextuales (Genette, 1989: 12-13).

"La Bella Durmiente" es también un relato de larga tradición, aparentemente la versión de Perrault se basa en el cuento "Sole, Luna e Talia" del escritor Giambattista Basile, aunque se registran numerosas composiciones anteriores, entre ellas Perceforest, anónimo francés del siglo XIV. También tiene versiones en distintas manifestaciones artísticas, como: el ballet con música de Tchaïkovski, el largometraje de Disney (1959) y el cortometraje de Kihachirō Kawamoto (1990). En la literatura se pueden mencionar los poemas de Tennyson: "Sleeping Beauty" (1830) y "The Day-Dream" (1842), y se destaca la serie de obras plásticas "The Legend of Briar Rose" de Edward Burne-Jones.

"Caperucita Roja" ha sido uno de los cuentos más estudiados desde el enfoque psicoanalítico, del que se ocupa Marc Soriano (1975). Su versión más antigua parece ser la que se localiza en un relieve decorativo del palacio Jacques-Cœur (Burgues, Provincia de Berry), edificio del siglo XV. El autor de novelas gráficas Milo Manara tomaría al personaje para la publicidad del Chanel n. 5 (1998). Red Hot Riding Hood (1943) de Tex

\footnotetext{
${ }^{10}$ Betty Boop: Snow White (1933) de Dave Fleischer, por ejemplo.

${ }^{11}$ Leone Frollo, Fabrice Meddour, L'Hermenie-Looky, Lylian-Vessillier-Grosjean, KrassinskySchwendimann, Miguel Navia, etc.
} 
Avery ofrece una versión animada erótica del cuento, que tiene versiones en todas las técnicas de animación, en el cine y cientos de versiones ilustradas.

La enumeración nos permite mostrar que se trata de narraciones transtextuales (Genette, 1989: 9-10), derivadas de relatos cuyo desarrollo histórico mantiene también los rasgos distintivos de la narración transmedia:

Forma narrativa que se expande a través de diferentes sistemas de significación (verbal, icónico, audiovisual, interactivo, etc.) y medios (cine, cómic, televisión, videojuegos, teatro, etc.). Las narrativas transmedia no son simplemente una adaptación de un lenguaje a otro: la historia que cuenta el cómic no es la misma que aparece en la pantalla del cine (Scolari, 2013: 24).

Las diferencias semánticas, argumentales, en los personajes, funciones y estrategias narrativas, se llegan a manifestar en un mismo medio, pues son muy distintas las historias sobre Caperucita que refieren los hermanos Grimm y la que había referido Charles Perrault, y tales diferencias encajan en otro de los rasgos que Scolari identifica como característico de las narrativas transmedia, pues cada versión: "debe ser lo suficientemente autónoma [...], no debes ver la película para entender el videojuego, y viceversa" (Scolari, 2013: 24). A esta autonomía de cada versión se añade que el conjunto configura mundos narrativos, definidos como:
"sistemas abstractos de contenido a partir de los cuales un repertorio de historias de ficción y personajes puede ser actualizado o derivado hacia una variedad de formas mediáticas" [... y] tanto el público como sus creadores comparten una misma imagen mental de la worldness, o sea una serie de rasgos que distinguen un determinado universo narrativo [...] un transmedia world puede comenzar en cualquier medio (Scolari, 2013: 26).

Estos aspectos también han sido observados por Long (2007:16), y reforzados por Scolari, al señalar las narrativas transmedia como una red de personajes y sucesos, que es resultado de una producción integrada (Scolari, 2013), en la que se producen conexiones entre las distintas 
versiones que, a la vez, mantienen autonomía, y pueden ser resultado de la contribución creativa colectiva, incluso de los receptores que la retrasmiten y/o recrean (arte de seguidores, parodias, etc.).

La mayoría de los cuentos de Carter se habían difundido antes de la edición del libro (Mauder, 2007: 89; Rushdie, y Carter, 2006: 461), que manifiesta vínculos entre los distintos relatos, por incluir referencias a personajes o detalles compartidos por los textos del volumen (intertextualidad autárquica, Dällembach, 1976: 282-296). Todos los cuentos enfatizan el papel de los personajes femeninos, positivos y negativos $^{12}$, ofrecen desmitificaciones y re-mitificaciones de las figuras masculinas, incluyen la recreación de tópicos de los relatos maravillosos, exponen aspectos perversos de la sexualidad o del matrimonio, emplean la humanización de animales y la animalización de los seres humanos, incluyen los mismos materiales intertextuales (intertextualidad general, Dällembach, 1976: 282-296) y alusiones a elementos del universo real que se introducen en el universo fantástico. Es decir, se trata de un volumen integrado, en el sentido en que Brescia y Romano (2006: 7 y ss.) entienden esta denominación.

Los escritos de Carter también participan de transmedialidad: el cuento considerado como el más logrado de la autora, daría lugar a un guion que ella publicaría en The Curious Room: Plays, Film Scripts and an Opera (1996), y al filme homónimo The Company of Wolves (1984) dirigido por Neil Jordan, cuyo guion fílmico resultó de una colaboración entre la escritora y el director. "The Company of Wolves" y "Puss-in-Boots" se adaptaron para programas de radio de la BBC (1980 y 1982). "The Bloody Chamber" y "The Tiger's Bride" dieron lugar a obras de teatro. La banda británica de rock Daisy Chainsaw tomó "The Lady of the House of Love" para un video musical: "Hope Your Dreams Come True". El dúo de músicos The Parlor Trick presentó la canción "The Lady of the House of Love" en su álbum A Blessed Unrest (2012). Se han realizado diversas ilustraciones del libro en formatos diversos, incluyendo los digitales ${ }^{13}$.

\footnotetext{
${ }^{12}$ Aunque se señala feminismo en las versiones de Carter, no hay tales contenidos en varios relatos: "La niña de la nieve", "El cortejo del señor León", "El gato con botas". También encontramos caracterizaciones femeninas negativas y subordinadas voluntariamente al dominio masculino.

${ }^{13}$ Karash, Topher MacDonald, Ashley Edge, Yana Kachanova, Ben Jones, Iro Tsavala, Sørensen, Sam Kerwin, Ceryn McCarthy, Marcin Potoczny, Chloe Robinson, etc.
} 


\section{LAS ILUSTRACIONES Y SU ANÁLISIS}

El volumen que estudiamos también está conformado por dieciséis ilustraciones, diez de diseño clásico a página completa, en formato vertical, y seis a doble página, en formato horizontal, realizadas con la técnica de collage, que Acosta ha empleado en casi todas sus ilustraciones de obras literarias, en un estilo que remite al que emplea Max Ernest para sus novelas gráficas, la más famosa Une semaine de bonté (1934) ${ }^{14}$. Estilo que Acosta recrea, usando también grabados que refieren a una iconografía del siglo XIX; aunque aquí Acosta introduce el uso de notas de color contrastantes (en rojo), rompiendo con el monocromatismo.

Mediante estas ilustraciones, el libro se transforma en obra multimodal que emplea dos sistemas de signos distintos, verbales e iconográficos, ambos perceptibles visualmente, pero con normas de expresión, lectura y funcionamiento diferentes, que entran en relación. Sin embargo, García Rodríguez caracteriza los libros ilustrados como aquellos "en los que las ilustraciones están dispersas de forma aleatoria por el texto, no son esenciales para comprender la historia y simplemente se utilizan para relajar la lectura, para completar y adornar" (García, 2011: 50). Esta caracterización ignora que al poner en relación imágenes y palabras, la importancia y funcionamiento de las primeras puede variar y ampliarse notablemente, fenómeno observado por diversos estudiosos como William Moebius (1989), Hernández (2010), Ravelo (2010), Ordoñez-Trujillo (2018), etc. Perales y Jiménez (2002), por ejemplo, señalan algunas de las funciones que las ilustraciones desempeñan en libros ilustrados: embellecer, informar, auxiliar en la comprensión, aportar contexto, sustituir a las palabras, incrementar la eficacia comunicativa, provocar reacciones afectivas, complementar, comentar, precisar el sentido, describir o explicar relaciones, situaciones y fenómenos; evidenciar ideas o contenidos, mostrar aspectos con claridad, reforzar. Anotan que esas funciones varían notablemente dependiendo de las relaciones que entre texto e imagen se establecen, la compaginación, la inclusión o no de etiquetas verbales, así como de otros aspectos: tipo de contenido que ilustra la imagen, finalidad de la misma, elementos formales de la imagen, polisemia de la

${ }^{14}$ El estilo identificado con los collages de Ernest puede localizarse también en: La enciclopedia de la abuela en 13 volúmenes (1963) de Walerian Borowczyk y en Laberinto (1962) de Jan Lenica. 
imagen, tipo de códigos que se emplean en ella y grado de complejidad, secuencialidad o ausencia de ésta, nivel de especialización implicado en los signos iconográficos, etc. (Perales y Jiménez, 2002: 369-386). Esta diversidad de funciones se amplía notablemente en las obras no científicas, ni de tipo didáctico.

Por su parte, Barthes señala que imágenes y palabras son dos tipos de estructuras "conformadas por unidades heterogéneas" (Barthes, 1992: 12), cuando las imágenes y las palabras conservan espacios reservados, aunque sean contiguos en una obra, recomienda analizar cada estructura por separado, para después precisar la manera en que se relacionan (Barthes, 1992: 12), ya se trate de imágenes que tienen un entorno textual (explicativo, informativo, complementario), como ocurre en libros de arte; o de textos verbales acompañados por un entorno de imágenes (ilustrativas, explicativas, complementarias, etc.), como ocurre en libros ilustrados y notas periodísticas.

Si bien, los libros que han sido ilustrados a posteriori, o fueron concebidos como texto sin imágenes, se caracterizan por una autonomía de las ilustraciones, en el libro que estudiamos, las obras visuales que acompañan a los relatos también tienen su propia autonomía. No se trata de obras cuyas significaciones requieran de los relatos para expresar un sentido, lo cual ocurre frecuentemente con obras que ilustran historias que forman parte de una memoria cultural colectiva (mitos, pasajes religiosos), pero también con cierto tipo de ilustraciones, que pese a las relaciones intertextuales que manifiestan, no se subordinan a una dependencia del escrito para su comprensión, aunque al establecer dicha relación la lectura se vea afectada por un fenómeno de contextualización significativa, que afecta imagen y escrito.

Para precisar, observaremos que la primera ilustración del volumen muestra una escena interior con dos personajes: una joven vestida de blanco, al estilo impero, acompañada por un hombre de pie, con smoking y sombrero de copa. Ella está sentada en un diván rojo, visto parcialmente, pues es cubierto por hojas que figuran en primer plano, en el ángulo inferior derecho, y se extienden hasta el regazo de la joven.

Separado del contexto del relato, el collage remite en primera instancia a un intertexto pictórico, el Retrato de Juliette Récamier (1805), de François Gérard, en una reproducción gráfica que ha sido intervenida de varias formas, no sólo por la inclusión del personaje masculino 
inclinado detrás de ella, semioculto por una pesada cortina que se levanta parcialmente para dejar ver al hombre que con su dedo índice parece tocar una gargantilla roja colocada en cuello de la joven. La mano del hombre ha sido superpuesta de manera que cubre parte del rostro femenino, dejando sólo visibles: uno de sus ojos, la frente, las cejas y parte de la mejilla derecha de la muchacha, cuyos cabellos quedan semicubiertos por una mantilla corta de encaje negro. La celebridad del lienzo - aunque menor que la del retrato de Jacques Louis David - y de la mujer retratada uno de los personajes femeninos más famosos del París Napoleónicoinclinarían al receptor, que reconoce el intertexto, a ver en este collage una nueva interpretación del personaje histórico y de algunas circunstancias que rodearon su vida ${ }^{15}$.

Sin embargo, esta obra figura en relación con el relato "La cámara sangrienta", por lo que dicho contexto afecta el sentido que en el volumen adquiere la obra visual, se trata de la misma precisión semántica que afecta cualquier signo en un contexto específico. De modo que el receptor debe leer la imagen como la representación de uno de los personajes del relato, la joven que se describe con un vestido blanco y una gargantilla de rubíes: la protagonista-narradora del cuento, que pese a ofrecer características peculiares que subvierten las representaciones femeninas típicas de los cuentos de tradición oral (Fuentes Martínez, 2004: 92-95), comparte con Juliette Récamier la nacionalidad, así como haberse casado con un hombre rico mucho mayor que ella. Ese contexto en que figura la imagen también nos lleva a ver en el hombre que la acompaña, al personaje masculino que obsequia a la protagonista la gargantilla: su futuro marido, nueva versión de Barba Azul que nos ofrece Carter. Este fenómeno de resignificación de la imagen corresponde a lo señalado por François Rastier: "la actualización de los componentes semánticos, incluso inherentes, está condicionada por el contexto" (1993: 36) que determina la inhibición o bloqueo de ciertos componentes semánticos, su activación o su propagación (incluyendo su alteración, sentido metafórico, arbitrario, o su vinculación semántica). A su vez, la imagen también incorpora al relato ciertos significados que no figuran en el escrito, pues, el lector que no identifica el material intertextual verá en este collage a una joven de cabello oscuro, con una mantilla corta

${ }^{15} \mathrm{La}$ importancia de su matrimonio con el banquero Jacques Recamier, veinticinco años mayor, su preferencia por ciertas joyas, las leyendas sobre su matrimonio. 
de encaje en la cabeza, que mira hacia el espectador mientras un hombre está próximo a ella, y esa joven, cuyo tipo somático no corresponde al que es descrito en el relato ("the frail child"), representa a un personaje que no muestra interés, amor, deseo, ni intimidación por la figura masculina que la acompaña. Elementos que ofrecen una interpretación distinta del personaje y la situación, que los que describe el relato, lo que no deja de ser significativo, particularmente si consideramos el contexto sociocultural de recepción de la obra traducida al castellano. Además, la ilustración también ofrece una interpretación distinta del personaje masculino, pues no se trata de: "Un hombre enorme, un hombre gigantesco", de "ojos oscuros e inmóviles como los ojos de los antiguos egipcios"16 (Carter, 2017: 16), de "melena rizada" y "revuelta" 17 (Carter, 2017: 53), ya que vemos hombre en atuendo formal que corresponde a una estatura promedio. De manera que la descripción que ofrece la narradora, al ser comparada con la imagen, es susceptible de ser interpretada por el lector como una visión subjetiva de la protagonista (tanto de sí misma, de la situación, como del personaje masculino), observados en la imagen desde el punto de vista de un testigo próximo a los acontecimientos, presentados ahí de un modo diferente, y en un contexto de recepción en el que tradicionalmente se atribuye a las imágenes la función, no sólo de ser mímesis de lo real, también de ser evidencia de lo acontecido o narrado ${ }^{18}$.

Para el receptor que contextualiza e identifica el intertexto pictórico, la ilustración ofrecería una versión de la protagonista del cuento, que está relacionada con el personaje histórico y las leyendas sobre Madame Récamier y su matrimonio, incorporando nuevos significados al relato, ofreciendo una lectura remodelizada de los acontecimientos históricos a que remite el personaje, modificando la interpretación del cuento que participa así de referentes históricos que el escrito no involucraba.

Con frecuencia las ilustraciones artísticas se alejan de la literalidad del texto ilustrado y esto no constituye necesariamente un defecto (salvo quizás cuando se trata de obras científicas o periodísticas, por ejemplo); pero aquí buscamos destacar la forma en que las ilustraciones pueden incorporan otro punto de vista por medio del encuadre, que implica una

\footnotetext{
16 "A huge man, an enormous man, and his eyes, dark and motionless as those eyes the ancient Egyptians".

${ }^{17}$ En el original: "His curling mane was disordered".

${ }^{18}$ Función señalada por Barthes cuando en la imagen destacan los rasgos miméticos.
} 
distancia, por medio de la angulación de la mirada que observa, pues "la imagen se presenta como un todo jerarquizado en niveles" (Grupo $\mu$, 1993: 32-33) $)^{19}$; o mediante el uso de sombras y luces ${ }^{20}$, las dimensiones y proporciones de los elementos visuales, elementos que aportan una serie de significados y connotaciones que el texto literario no contiene (expresados en la imagen mediante la estilización o efectos de realismo, los rasgos descriptivos, la importancia que se les otorga en la imagen, los intertextos visuales a los que remiten, etc.).

En la segunda ilustración del relato se observa, desde el punto de vista de un testigo ubicado en el interior de una habitación, el empapelado de un muro, en el que se encuentra una elaborada cerradura por cuya abertura se asoma un ojo que mira hacia el potencial observador del collage, pueden verse también: un cuerpo femenino desnudo recostado y salpicado por un líquido rojo que parece inundar la habitación, así como una cortina próxima a la cerradura. Estos elementos sugieren una escena de crímenes, de encierro, un acto de voyerismo, que apela al espectador potencial, que mira y es mirado (desde la imagen), permitiendo varias interpretaciones. Sin embargo, cuando se identifica que el cuerpo femenino desnudo y el agua del collage, provienen de uno de los grabados de Doré, elaborados para ilustrar el "Canto VIII" (versos 39-40) del "Infierno" de Dante Alighieri, se modifica notablemente el sentido de la escena, ya que en el contexto del grabado original, el agua es el Estigia y el personaje femenino representa una de las almas condenadas, por su ira, a hundirse en el líquido lodoso de ese río. De este modo el collage, separado del texto literario que ilustra, para quien reconoce el intertexto (Eco, 2003), ofrece una nueva versión de una escena dantesca, observada por el ojo de una cerradura por un personaje anónimo ubicado en un espacio distinto a la habitación que nos remite al quinto círculo del infierno de la Divina Comedia.

Al poner en relación el collage con el relato del que es ilustración, contexto al que ha sido integrado en el libro, el lector debe reconocer en ese espacio: la recámara prohibida donde el marqués guarda los cadáveres de sus esposas, y en el ojo que mira a través de la cerradura, la mirada de la narradora-protagonista del cuento. Sin embargo, ese lector también

\footnotetext{
${ }^{19}$ Un personaje visto desde abajo nos coloca en un nivel inferior respecto a él; en vista en picado, nos coloca en un nivel de superioridad.

${ }^{20}$ Que puede ocultar o destacar elementos, suavizar las líneas o endurecerlas, confundir o separar límites.
} 
capta que la escena de la ilustración no ha sido referida en el cuento, esta ilustración narra visualmente un instante que se supondría previo al ingreso de la protagonista a la recámara prohibida, anticipando y fusionando en un mismo momento: el hallazgo del cadáver desnudo de la cantante de ópera y el momento en que la protagonista encuentra el cuerpo de la condesa rumana y de sus manos cae la llave de la habitación en un charco de sangre (Carter, 2017: 42-43). La imagen ofrece una versión distinta de lo narrado, al incorporar algo que no se cuenta en el relato y al fusionar momentos diferentes, al destacar el acto de voyerismo que implica aquí la intrusión en el espacio prohibido. Por lo que la imagen releva la función de la narradora, añadiendo elementos a su relato, comentando visualmente lo narrado y ofreciendo otra concepción del orden de las acciones. Si a esto se añade el reconocimiento del material intertextual, la imagen introduce un referente que no figura en el escrito, con importantes consecuencias semánticas, en tanto el espacio prohibido es caracterizado como uno de los círculos del infierno dantesco y las víctimas quedan connotadas por el concepto del pecado, ofreciendo una razón a las acciones del agresor ${ }^{21}$.

En la tercera ilustración del primer relato del libro también es visible un intertexto proveniente de los grabados de Doré - esta vez del "Canto XVII" (versos 130-132) de la Divina Comedia - y se describe la recámara prohibida, de la que en el cuento se han enumerado los instrumentos para suplicio dispuestos en la habitación: "la rueda, el potro y la doncella de hierro" (Carter, 2017: 43). En el collage, sin embargo, el personaje femenino del grabado de Doré es atravesado por varillas relacionadas con maquinarias modernas y no figuran instrumentos medievales de tortura, lo que modifica el sentido del relato, que aunque ubicado en una época imprecisa, por elementos que refieren a distintos periodos históricos, corresponde a un tiempo posterior a la difusión de las obras de Claude Debussy y al uso doméstico del teléfono, pero también a un contexto en el que perviven esquemas feudales (signo de ello es que la protagonista es marcada en la frente, y condenada por desobediencia a la decapitación por el tajo de un verdugo). Aquí la imagen contribuye a la actualización del cuento a un contexto más contemporáneo, al mismo tiempo que reemplaza la descripción de una mujer encerrada en una doncella de hierro, por un desnudo femenino que parece querer huir, pero se encuentra atrapado, por

${ }^{21}$ Como ocurre en el relato que enmarca las historias de Las mil y una noches. 
tubos que atraviesan distintas partes de su cuerpo.

Este collage, separado del cuento, también puede leerse como una nueva versión del pasaje ilustrado por Doré para la Divina Comedia, en que el personaje femenino representa a Thais, la prostituta condenada por adular a quien la había usado como objeto sexual. Y para el lector que no identifica el material intertextual podría resultar interpretable como una imagen en la que se victimiza a la mujer en un contexto marcadamente industrializado, introduciendo un significado que, como el pasaje ilustrado, no figura en el texto de Carter.

De este modo buscamos ejemplificar la importancia de la contextualización que hace el receptor, en la interpretación y semántica de los signos, la importancia de la ubicación de la imagen en una obra y la forma como los signos iconográficos y los intertextos específicos aportan sentidos, connotaciones, aunque aquí sólo destacamos los fenómenos involucrados por los cambios de contextualización.

La primera de las ilustraciones que acompañan al cuento "La novia del tigre", como las anteriores, guarda relación con las páginas que la preceden. De manera que, parte importante de lo narrado en el cuento antecede a la ilustración, que constituye una segunda versión para el lector de algunos asuntos relatados. En este caso se ha referido la forma en que una joven pasa a ser propiedad de un hombre-tigre. La ilustración omite muchas informaciones, no muestra el lugar de origen de la protagonista y su padre, tampoco las características de la población donde se encuentran, ni los rasgos con que se han caracterizado a los personajes, tampoco ilustra parte de la infancia y pasado reciente de la narradora, ni su situación. En la imagen se destacará la importancia de algunos elementos, que parecerían secundarios en el escrito, mediante la selección de un reducido número de detalles, que adquieren una carga simbólico-narrativa en esa imagen, cobrando protagonismo e incorporando matices, un punto de vista diferente al de la narradora, pues se muestra: en un primer plano un conjunto de flores, hojas y un ave, que connotan lo primaveral, y en un segundo plano: un par de manos sosteniendo naipes, una de ellas con los dedos cruzados como gesto que invoca la buena suerte. En un tercer plano hay una rosa encerrada en un capelo de cristal, y en un último plano dos enormes ojos felinos. En el cuento no se ha hecho referencia a la primavera, aunque se han contrapuesto el invierno ruso, al cálido clima de un país en que se bebe grappa, el sol "vierte frutos" y las mujeres poseen un "furioso 
cinismo", se han incluido indicadores topográficos y se ha enfatizado la humedad helada del lugar en que se encuentra la narradora. Por lo que las flores y el ave ofrecen una idealización del contexto. Se ha detallado una partida de naipes, en la cual, el padre viudo y adicto al juego, la bebida y los prostíbulos, ha apostado a su hija sin prever la posibilidad de perderla, siendo por ello recriminado por el ganador: la Bestia. Por lo que la idealización se percibe también al presentar visualmente esa situación. De modo tangencial, también se ha hecho referencia - entre la enumeración de características físicas y penurias de la protagonista - a la identificación que una niñera inglesa hiciera de la joven con una rosa. Por lo que el lector atento identifica en la rosa del collage la representación simbólica de la joven, protegida por un capelo de cristal, lo que no elimina el fenómeno de su reducción a objeto que se apuesta (se pone en la mesa de juego) que la afecta en la partida de cartas. Además, el hombre tigre ha sido descrito por la narradora desde un enfoque desmitificador y crítico, señalando su figura desgarbada, su olor perturbador, sus toscos guantes, su torpe forma de expresarse, y sólo ha mencionado sus ojos en una ocasión, para señalar que se desviaban hacia ella; pero en la imagen son los ojos felinos los que representan al personaje, ofreciendo una perspectiva distinta de él, como quien domina desde el fondo todo lo que parece empequeñecido ante sus enormes ojos que ocupan la parte superior del campo, delimitando el eje central en que figura la rosa. La imagen nos ofrece, lo que parecería ser la visión subjetiva de un personaje del cuento, que invoca la suerte en el juego y privilegia aspectos que la narradora no ha privilegiado en su relato. Dado que se ofrece después de lo narrado y tiene la elocuencia atribuida a toda imagen figurativo-mimética, podemos señalar que funciona como demostración sintético-conclusiva de los acontecimientos, discriminando datos y privilegiando otros, jerarquizándolos y connotándolos con ciertos significados, mediante la selección, composición, rasgos, y ubicación en los planos de los elementos visuales, y mediante la sintaxis espacial propia de una imagen de formato rectangular vertical. Por lo que la ilustración no corresponde a un paratexto (Genette, 1989: 11-12), se trata de una imagen que caracterizan personajes, muestran hechos, desde un punto de vista distinto al del escrito, ofreciendo su propia versión de la obra, respecto a la cual establecen relaciones precisas de hipertextualidad (Genette, 1989: 14-17), como el lienzo que ofrece su versión de uno de los componentes de un mito o de una anécdota bíblica. Pero en este caso se trata de una 
imagen que también posee autonomía, pues la imagen permite una lectura independiente del cuento de Carter, como reinterpretación de la "Bella y la Bestia", sobre todo porque la rosa en un capelo forma parte de la iconografía del filme de Disney, ampliamente difundido.

La segunda ilustración del mismo cuento permite ejemplificar otras funciones. Muestra una escena que tiene lugar en un espacio caracterizado como exterior, en el que hay vegetación (flores en botón, hojas, frutos rojos), una mariposa, una pareja de caballos y una joven de pie con el pecho desnudo, con un velo blanco de encaje sobre el rostro, mirando hacia un punto que queda fuera del campo de la imagen. Todos los elementos son vistos parcialmente y a una proximidad que corresponde a la de un encuadre de tres cuartos de la figura humana, de los dos caballos que la acompañan sólo se ven sus cabezas, próximas entre sí y en plano adelantado a la joven, que ocupa el eje vertical central del campo visual.

Correlacionada con el cuento, esta imagen parecería ser la que mayor dependencia guarda respecto al escrito, pues ilustra el pasaje en que la joven accede a la petición del hombre-tigre, luego de que él se ha mostrado sin máscara y sin ropas humanas: "Mostré a su silencio grave mi piel blanca, mis pezones rojos, y los caballos giraron las cabezas..." (Carter, 201: 100). Sin embargo, separada del texto al que acompaña, la imagen es también susceptible de ser interpretada como una versión parcialmente transgresora ${ }^{22}$ de Lady Godiva ${ }^{23}$, que también puede señalarse como material intertextual en el relato de Carter. Sin embargo, un fenómeno que nos interesa destacar en relación con esta imagen no es su doble interpretación posible; la función que buscamos ejemplificar deriva de su relación con el cuento que ilustra. Ya que, en el cuento de Carter, la narradora-protagonista ha hecho referencia al escrito más célebre de Jonathan Swift (1726), específicamente al capítulo IV de dicha obra. Esta referencia, previa al pasaje ilustrado, tiene consecuencias en las connotaciones semánticas que la ilustración adquiere, pues la joven que muestra su desnudez lo hace en compañía y proximidad de los seres animales que ella considera más sabios que los hombres, concordando con Jonathan Swift, detalle que la ilustración hace evocar por asociación,

\footnotetext{
${ }^{22}$ Por tener el cabello corto, al mismo tiempo que "cubre" su rostro con un velo.

${ }^{23}$ Personaje histórico que dio lugar a una leyenda con numerosas versiones artísticas, y que utilizó Freud para su desarrollo teórico del voyerismo.
} 
aunque también y de manera inmediata, la presencia de los caballos refieran a las monturas de los dos protagonistas del cuento de Carter, que se encontraban cabalgando antes del pasaje ilustrado. La imagen contribuye así a destacar un elemento intertextual, que constituye una clave importante de la semántica de este relato de Carter, en el cual ofrece una crítica a la naturaleza humana, colocando la naturaleza animal, no en lugar del ser inferior sino, connotada de belleza, por encima de los vicios, valores económicos y costumbres humanas. Semántica que se hace evidente si recordamos que en el cuento son los intentos por imitar lo humano, los que hacen ridícula a la Bestia ante los ojos de la narradora, y que no será la Bestia quien se transforme en hombre; sino la joven quien se transforme en bestia al final del relato, subvirtiendo el sentido habitual del mismo. De este modo, la ilustración contribuye a destacar el contenido semántico principal del relato, no se limita a ilustrarlo, predominando aquí relaciones complementarias, de ampliación y énfasis, en la producción de significado.

La ilustración también puede describir algo marcadamente diferenciado de lo que el relato narra. Este fenómeno se verifica en el collage que acompaña al cuento "La niña de la nieve", texto que de manera más notable apela a la visualidad, a la hipotiposis (Eco, 2003: 254-255), al cromatismo del blanco, negro y rojo. En la ilustración se destacará, en cambio, la importancia de las texturas y formas, las relaciones entre fondo y figuras. Pues, sobre un fondo gris de leve textura irregular se observa el entramado de un encaje blanco, y casi en el centro, recostada de espaldas y desnuda, una joven envuelta por la cola de una piel de zorro, cuatro cuervos están parados sobre su muslo derecho y ella sostiene una larga pluma negra. El encaje blanco, en el que se destaca la textura visual (mediante texturemas definidos y magnificados en su dimensión), es un tejido traslucido - que dejar entrever otro fondo, agrisado- y constituye a su vez, la base sobre el que se destacan un conjunto de formas (Grupo, $\mu, 1993$ : 190), que producen la impresión de solidez, volumen, y cuyas dimensiones, al ser comparadas con las del encaje, resultan reducidas en una proporción antinatural, pues la figura humana, las aves, la pluma y la piel de zorro, ocupan el espacio equivalente a un reducido número de hojas del diseño del encaje, produciendo el efecto de que la dama y los animales son diminutos. Y por lo que respecta a la direccionalidad de las formas sólidas de la imagen (Grupo $\mu, 1993$ : 190), éstas se contraponen 
a las del encaje, por destacarse la horizontalidad de la figura femenina, y en el resto de elementos las diagonales en oposición a los tallos foliados del fondo. El elemento morfológico que, pese a su dimensión, domina el conjunto semántico visual principal, es el de esa joven recostada, sobre una oscura piel animal, cuya desnudez sólo es parcialmente cubierta (por las aves negras y la piel de zorro que la envuelve parcialmente). La joven muestra su rostro de perfil, mientras levanta y dobla el brazo derecho, sobre el que descansa su mano izquierda que sostiene la pluma del ave. Para el receptor, la imagen ofrece un desnudo femenino, en un entorno donde se identifican elementos que connotan cierto fetichismo (encaje, pieles), y alude a una naturaleza connotada de sensualidad (flores, aves, pieles animales). Para quien contextualiza histórica y socioculturalmente los elementos iconográficos, la imagen es interpretable como una versión del nacimiento de Venus ${ }^{24}$, que en lugar de nacer de la espuma se recorta sobre encaje blanco. Venus Calipigia, pero también Venus de las pieles (de Sacher-Masoch), que evoca también la de Rokeby (considerada el más célebre desnudo del arte español).

En relación con el cuento de Carter, que ofrece una versión más breve y subversiva ${ }^{25}$ del texto Nathaniel Hawthorne, "The Snow Image a Childish Miracle" y de "Blancanieves"; la ilustración modifica la anécdota referida por la escritora, no sólo por alterar la edad de la niña desnuda que protagoniza el cuento de Carter, y cuyo cadáver es objeto de la violencia sexual explícita por parte del conde. La imagen también omite la referencia a una niña herida que sangra y se desvanece, remplazándola con una joven recostada en pose, ofreciendo su desnudez a la mirada. El receptor percibe la notable variante de la versión visual respecto a la descrita en el cuento. La reinterpretación visual elimina: los contenidos relacionados con la pederastia, el incesto, la violencia y perversión sexual del padre, los celos y desaprensión de la madre, centrales en el relato de Carter, así como la ironía macabra. Al mismo tiempo se ofrece una caracterización distinta de la víctima, identificable por el ala del cuervo, y esta reinterpretación modifica y reduce lo narrado, elimina las connotaciones específicas que

\footnotetext{
${ }^{24}$ Bernardino Nocchi y Giovanni Folo, representarían el Nacimiento de Venus, mediante una Venus Calipigia recostada.

${ }^{25} \mathrm{Al}$ representar lo opuesto a una madre afectuosa y orgullosa de sus hijos, y a un padre que actúa procurando el bienestar de quien supone es hija de un vecino.
} 
tienen algunos de los indicadores de estatus ${ }^{26}$, que en la imagen sólo conservan su connotación erótica (las pieles y la desnudez femenina), evacuando la violencia de las relaciones sexuales y de clase social descritas en el cuento.

En contraste con el caso anterior, la caracterización del personaje de la protagonista se ajusta al relato que ilustra, sin alterar el sentido del cuento y sus acciones, en la ilustración que acompaña a "El hombre lobo": al presentar la figura de una niña, cubierta por una piel oveja, vestida de rojo, sosteniendo un cuchillo, en un paraje boscoso y en actitud casi militar. Imagen también interpretable como una nueva versión de Caperucita Roja, como una diestra cazadora-niña que se cubre con una piel de oveja y viste de rojo.

Podemos distinguir en el libro, imágenes que tienen o adquieren funciones narrativas, al ilustrar o reinterpretar acciones y detalles que aluden a elementos anecdóticos y situaciones específicas, como las que acompañan a: "La cámara sangrienta", "La novia del tigre", "El cortejo del señor León", "El gato con botas". Otras que contribuyen a la caracterización de personajes, como las que acompañan a: "La niña de la nieve", "El hombre lobo", "El rey de los trasgos", "La compañía de los lobos". Pero, estas funciones dependen tanto de los elementos contenidos en la imagen, como de los contenidos en los escritos, y de las relaciones específicas que entre ambos sistemas sígnicos se producen.

\section{CONCLUSIONES}

El análisis de las ilustraciones y sus relaciones con el escrito permite observar la forma en que ponen en crisis su caracterización como elementos accesorios (Genette, 1989: 11), desvinculados de los procesos semióticos. Nos lleva a considerar la pertinencia de concebir el libro ilustrado como un tipo de texto-integrado en el que signos verbales e iconográficos interactúan en una obra no necesariamente producida por un solo autor, que se presentan al receptor como una unidad, exigiendo con ello una lectura que debe considerar todos sus componentes como

\footnotetext{
${ }^{26}$ Se señala que se trata de condes que han salido a montar sobre dos yeguas, la condesa lleva pieles, botas negras y espuelas, guantes, un broche de diamantes. Sus bienes pasan a la niña luego que su marido la monta en su caballo.
} 
portadores de significado. Nos conduce a concebir el libro ilustrado como conjunto de obras literarias y visuales que conforman un texto que participa de signos provenientes de dos sistemas semióticos distintos constituyendo otro sistema específico, en el que los diversos signos y obras copresentes poseen sus propias normas de interacción, que no sólo colaboran, también se contraponen, se pueden reforzar, subordinar, o separar, en una dinámica compleja. En el caso analizado se trata de una obra conformada por elementos, literarios y artísticos, que permiten lecturas independientes del volumen en que se les ha reunido (distintos cuentos, diferentes collages), pero que al ser leídos de manera integrada introducen, refuerzan, orientan, destacan o modifican ciertos significados, precisando también los tipos de funcionamiento generados por su interacción, cuyos significados sólo en parte son derivados de los sistemas semióticos de los que los signos y textos provienen, pues otros derivan del funcionamiento que desempeñan dentro del sistema integrado.

Estudiar las ilustraciones de en un libro como intertextos -que pueden ofrecer diversos tipos de relación con las obras escritas (variante, alusión, parodia, nueva versión, etc.) - permite precisar la manera en que llegan a involucrar contenidos que el hipotexto (Genette, 1989) no involucra. Al analizar el modo en que se eliminan contenidos presentes en el escrito, y establecer relaciones con otros textos distintos a los del escrito ilustrado, se identifican significados y connotaciones. Esta compleja imbricación de lenguajes, no corresponden a los fenómenos de una traducción intersemiótica, pues quien "traduce debería hacer todo lo posible para expresar lo que dice el texto fuente" (Eco, 2003: 279) y esto pese que "toda traducción presente unos márgenes de infidelidad con respecto a un núcleo de presunta fidelidad" (Eco, 2003: 23) cuyos márgenes pueden ser muy variables, pero que hacen posible discernir una traducción, de una parodia, o de una reformulación o refundición radical. Por ello resulta pertinente estudiar la ilustración como fenómeno hipertextual o intertextual (Genette, 1989), y no como traducción, eliminando también así la problemática de identificar toda nueva versión con una traducción, que conlleva, entre otros problemas, la dificultad de decidir, por ejemplo, si el director de un filme debería firmar como traductor de la novela que reinterpreta en su película. La recuperación de elementos textuales en otro sistema sígnico, concebida de modo generalizado como traducción, impide hacer distinciones que es obligado establecer en todo análisis semiótico, 
diferenciar fenómenos intertextuales distintos, como son: la traducción, cita, variante, alusión, o subversión semántica extrema de una obra previa.

Nuestras conclusiones se contraponen a las formulaciones que buscan generalizar las funciones posibles que las ilustraciones desempeñan en relación con un texto, y difieren de algunas que diversos investigadores han identificado en las propuestas teóricas que parcialmente adoptamos aquí. Esto último se destaca si consideramos la lectura esquemática que hace Orrego de las consideraciones de Barthes: "Barthes identifica tres posibles relaciones entre texto e imagen [...: Ilustración (en que la imagen dilucida o aclara un texto); anclaje (en que [...] es el texto el que aclara o dilucida la imagen); y relevo (en que estos dos elementos se encontrarían en un mismo nivel)" (2011: 63); pues nuestro estudio hace patentes funciones que no encajan en este reducido número de variables.

La importancia de la contextualización de los signos, en los procesos de interpretación, se hace también evidente en este análisis, sin menoscabo de la importancia de la especificidad de tales signos, sus rasgos significantes, su amplitud semántica y cultural específica, como elementos fundamentales para la generación de significado. Al mismo tiempo que se destaca el papel que la competencia cultural del receptor desempeña también en la lectura de las imágenes, cuando se identifica o no un material intertextual visual, la referencia a un tema iconográfico clásico, etc.

El estudio también nos lleva a confirmar la relación que se produce entre el concepto de transtextualidad desarrollado por Genette y el de transmedia, pues si bien no todas las obras que involucran fenómenos de transtextualidad son transmedia, de acuerdo con los autores que aquí hemos considerado, toda obra transmedia involucra fenómenos de transtextualidad en alguna de sus modalidades particulares (sobre todo la intertextual).

También observaremos que el concepto de transmedia (Scolari (2003:24) viene a hacer explícito un aspecto que involucra implícitamente la transtextualidad de Genette: "todo lo que pone al texto en relación, [...], con otros" (Genette, 1989: 9-10), debido a que da denominación al tipo de relaciones transtextuales específicas que se establecen entre obras distintas - ya sean multimodales o no-, que involucran distintas formas mediáticas (Scolari, 2013: 26). Concebir la forma mediática como el medio de comunicación vinculado indisociablemente a tecnologías y soportes materiales muy específicos (Scolari, 2003), y diferentes a los 
de la forma mediática en que se difundió (y/o produjo) el texto que es recuperado posteriormente en otros, hace que el concepto de narrativa transmedia (acuñado por Marsha Kinder en 1991) no pueda interpretarse como una denominación dada, por los estudiosos de las tecnologías de la comunicación (Jenkins, 2003), a la transtextualidad de Genette (1962, en su edición francesa), que aunque tiene su origen en los estudios literarios, no se limita a éstos 27.

Asimismo, pudimos destacar la particularidad de los fenómenos integradores que involucra el libro ilustrado, al poner en relación obras distintas que, sin embargo, mantienen autonomía, generando una red textual similar a la de las narrativas transmedia, susceptible también de abrirse al receptor que potencialmente se puede incorporar como cocreador del universo conformado por los distintos textos, propiciando un fenómeno de creación colectiva.

Respecto a las implicaciones que el conjunto integrado conlleva, la mayoría de los estudiosos habla de una búsqueda de lo totalizante y el interés, al emplear el recurso, por hacer manifiesta la conciencia del autor sobre el carácter relacionado de sus textos. Nosotros identificamos, en La cámara sangrienta, también: la expresión de unidad en la diversidad, generada por ciertos elementos que sirven de conectores; y diversidad dentro de un marco de similitudes, un dinamismo que apela a reinterpretaciones de textos que entran en interacción, generando contradicciones que ponen en crisis una tradición narrativa previa.

La autonomía de las obras en las narrativas transmedia no sólo debe considerarse desde un enfoque de la mercadotécnica, en tanto que sirve para generar productos consumibles por separado, que es el enfoque que han privilegiado algunos estudiosos, como señala Scolari (2013: 24), también debe considerarse como elemento que busca destacar la singularidad dentro de la homogeneidad relativa, producida por la integración.

El grado de autonomía de las ilustraciones de Alejandra Acosta es un fenómeno que responde a las características de sus obras, entre las que se encuentra la técnica utilizada para su producción, pero las ilustraciones de otras obras pueden contener un grado distinto de autonomía e incluso puede no involucrarlo. Del mismo modo, el grado de integración de los

${ }^{27}$ Sobra decir que Genette no se refiere sólo al texto verbal, en su estudio incluye referencias a la pintura, la música y el cine. 
distintos relatos puede ofrecer un nivel diferente de correlación en otras colecciones de cuentos y libros integrados, en otros casos.

\section{REFERENCIAS BIBLIOGRÁFICAS}

BERLANGA FERNÁNDEZ, I.; ARJONA MARTÍN, J. y MERINO ARRIBAS, A. (2018). "Semiótica digital en la serie de ficción El ministerio del tiempo". Signa 27, 233-262. Disponible en línea: http://revistas.uned.es/index.php/signa/article/view/18413 [14/06/2019].

BRESCIA, P. y ROMANO, E. (2006). El ojo en el caleidoscopio. México: UNAM.

CALVINO, I. (2014). Cuentos populares italianos. Madrid: Siruela.

CAMILlE, M. (1992). Image on the Edge. The Margins of Medieval Art. Londres: Reaktion Books.

CARTER, A. (1979). The Boody Chamber and Other Adult Tale. New Yotk: Harper \& Row.

(2017) La cámara sangrienta. México: Sexto Piso.

COLOMER, T.; KÜMMERLING-MEIBAUER, B. y SILVA-DÍAZ, M. C. (2010). Cruce de miradas: Nuevas aproximaciones al libro-álbum. Barcelona: Banco del Libro-Gretel.

CRESPO, B. (2017). "Consideraciones sobre transmedialidad, interdiscursividad e interactividad comunicacional en el Libro-arte digital (Hiperlibro-arte)". Arte, Individuo y Sociedad 30, 95-110.

DÄLLENBACH, L. (1976). "Intertexte et autotexte". Poetique 26, 282296.

DI MARCO, M. (2017). "Poesía infantil y diálogo intersemiótico: la teoría de la lírica frente a un receptor niño que lee imágenes". Meridional 9, 355-379.

DURÁN, T. (2009). Álbumes y otras lecturas. Análisis de los libros infantiles. Barcelona: Octaedro.

ECO, U. (2003). Decir casi lo mismo. Barcelona: Lumen.

ERRO, A. (2000). "La ilustración en la literatura infantil". Rilce 16, 501511.

FALCON, P. (1999). "El manuscrito ilustrado". En III Jornadas de Canto Gregoriano: scriptoria y códices aragoneses, P. Calahorra y L. 
Prensa (eds.), 51-100. Zaragoza: Institución Fernando el Católico. GARCÍA RODRÍGUEZ, A. (2011). Análisis estructural del subsector de la edición infantil y juvenil en Castilla y León (1983-2000). Salamanca: Ediciones de la Universidad de Salamanca.

GENETTE, G. (1989). Palimpsestos. La literatura en segundo grado. Madrid: Taurus.

(2001). Umbrales. México: Siglo XXI Editores.

GIL GONZÁlEZ, A. y PARDO, P. J. (eds.) (2018). Adaptación 2.0. Estudios comparados sobre intermedialidad. Binges: Orbis Tertius. HANÁN DÍAZ, F. (2007). Leer y mirar el libro álbum: ¿un género en construcción? Bogotá: Norma.

HENRY, S. (1951). La décoration marginale française dans les manuscrits du milieu du Xllf à la fin du XV siècle. Paris: École Nationale des Chartes.

HERNÁNDEZ, P. (2010). “Lugar, sujeción y mirada: relaciones entre imágenes y palabras en las artes visuales contemporáneas centroamericanas". Revista de Filosofía de la Universidad de Costa Rica 48, 107-113.

JAKOBSON, R. (1971). "On linguistic Aspects of Translation". En Selected Writings, 2. Word and Language, R. Jakobson, 232-239. The Hague-Paris: Mouton.

JENKINS, H. (2003). Rethinking Media Change: The Aesthetics of Transition. Media in transition. Cambridge: MIT Press.

KRESS, G. \& LEEUWEN, Th. V. (2001). Multimodal Discourse, the modes and media of contemporary communication. London: Arnold. (2003). Multimodality, multimedia and genre. Literacy in the New Media Age. London: Routledge.

LONG, G. (2007). Transmedia Storytelling: Business, Aesthetics and Production at the Jim Henson Company. Disponible en línea: http:// cms.mit.edu/research/theses/GeoffreyLong2007.pdf [18/11/2018].

MAUDER, A. (2007). The Facts on File Companion to the British Short Story. New York: Infobase Publising.

ORDÓÑEZ-TRUJILLO, D. C. (2018). "Relación entre la palabra y la imagen en Medias dulces de Ivar Da Col". Estudios de Literatura Colombiana 42, 99-115.

PERALES, F. J. y JIMÉNEZ, J. (2002). “Las ilustraciones en la enseñanzaaprendizaje de las ciencias. Análisis de libros de texto". Enseñanza 
de las Ciencias 20, 369-386. Disponible en línea: https://core. ac.uk/download/pdf/13268068.pdf [08/07/2018].

PROPP, V. (1974). Morfología del cuento. Madrid: Fundamentos.

PLANAS, J. (2009). "Un preludio del Renacimiento: el libro iluminado durante el período tardogótico en Cataluña”. En Arte de épocas inciertas. De la Edad Media a la Edad Contemporánea, M. del C. Lacarra Ducay (ed.), 285-339. Zaragoza: Institución Fernando El Católico.

RASTIER, F. (1993). “Complejidad semántica y contexto". Estudios de Lingüistica. Universidad de Alicante 9, 25-42. Disponible en línea: http://dx.doi.org/10.14198/ELUA1993.9.02 [10/09/2018].

RAVELO DE GOLDZAMD, L. C. (2010). Análisis de Maus de Art Spiegelman, historieta de guerra de final abierto. Trabajo de Fin de Máster: Universidad de Buenos Aires. http://repositorio.filo.uba. ar/handle/filodigital/1978 [11/10/2018].

RODRÍGUEZ FERRÁNDIZ, R. y PEÑA MARÍN, C. (2014). "Narraciones transmedia y construcción de los asuntos públicos. Introducción". Cuadernos de Información y Comunicación 19, 9-16.

RUSHDIE, S. \& CARTER, A. (2006). "First Publication". En Angela Carter. Collected Stories, 461-462. London: Vintage.

SCOLARI, C. A. (2013). Narrativas transmedia. Cuando todos los medios cuentan. Barcelona: Gobierno de España-Grupo Planeta.

SIPE, L. R. \& PANTALEO, S. (2008). Postmodern picturebooks. Play, parody and self-referentiality. New York: Routledge.

TOROP, P. (2000). "La traduzione totale". En Corso di traduzione, B. Osimo. Disponible en línea: http://courses.logos.it/plscourses/ linguistic_resources.cap_3_31?lang=es [10/01/2018].

(2002). "Intersemiosis y traducción intersemiótica". Cuicuilco 9, 25, 1-30. Disponible en línea: http://www.redalyc.org/articulo. oa? id $=35102502$ [18/01/2017].

TURRIÓN PENELAS, C. (2012). "La ambigüedad de significado en el álbum y su lector implícito. El ejemplo de El túnel de Browne". Bellaterra Journal Teaching \& Learninga Language \& Literature 5, 60-78.

VIANA, F. L.; MARTINS, M. \& COQUET, E. (2003). Leitura, Literatura Infantil, Ilustração: Investigação e Prática Docente. Braga: Universidade do Minho. 
WOLF, W. (2009). "Metareference across Media: The Concept, its Transmedial Potentials and Problems, Main Forms and Functions". En Metareference across Media: Theory and Case Studies, W. Wolf, K. Bantleon y J. Thoss (eds.), 1-85. Amsterdam/New York: Rodopi.

Recibido el 17 de enero de 2019.

Aceptado el 1 de junio de 2019. 